\title{
Personality Traits Related to Binge Drinking: A Systematic Review
}

\author{
Ana Adan ${ }^{1,2 *}$, Diego A. Forero ${ }^{3}$ and José Francisco Navarro ${ }^{4}$ \\ ${ }^{1}$ Department of Clinical Psychology and Psychobiology, University of Barcelona, Barcelona, Spain, ${ }^{2}$ Institute of \\ Neurosciences, University of Barcelona, Barcelona, Spain, ${ }^{3}$ Laboratory of Neuropsychiatric Genetics, School of Medicine, \\ Universidad Antonio Nariño, Bogotá, Colombia, ${ }^{4}$ Department of Psychobiology, University of Málaga, Málaga, Spain
}

The pattern of alcohol consumption in the form of binge drinking (BD) or heavy episodic drinking has increased notably worldwide in recent years, especially among adolescent and young people, being currently recognized as a global health problem. Although only a minority of binge drinkers will develop a substance use disorder, BD may have negative personal and social consequences in the short and medium term. The objective of this article is to review the findings on personality traits related to binge drinkers and to emphasize the aspects that should be examined in order to make progress in this area. The main characteristics of personality related to the practice of BD, regardless of the theoretical model used, are high Impulsivity and high Sensation seeking, as well as Anxiety sensitivity, Neuroticism (Hopelessness), Extraversion and low Conscientiousness. The data obtained may have theoretical implications to elucidate the endophenotype of $\mathrm{BD}$, but they are especially useful for their preventive applications. Integration into prevention programs of emotional self-control skills, decision-making, social skills, and strategies to manage negative emotions will minimize the risk factors or consequences of $\mathrm{BD}$ associated with personality and will improve their effectiveness. In the future, it is necessary to harmonize a common measurement instrument for the assessment of personality, develop longitudinal studies with large samples that also integrate biological and neurocognitive measurements, and determine the reciprocal relationship between personality and BD together with its modulating variables, as well as the possible cultural differences.

Keywords: binge drinking, heavy episodic drinking, personality traits, impulsivity, sensation seeking, neuroticism, anxiety, prevention

\section{INTRODUCTION}

The pattern of binge drinking (BD) or heavy episodic drinking is increasing and expanding worldwide (1). Although it is recommended to define the $\mathrm{BD}$ as the consumption of high quantities of alcohol ( $\geq 4 / 5$ drinks for women/men) within a time period of $2 \mathrm{~h}(2)$, there is no consensus and it is frequent to consider the consumption in one occasion/sitting. BD supposes an important public health problem of which it is still necessary to know better the vulnerability factors responsible for its initiation, maintenance, or increase in frequency and intensity.

Individuals who practice $\mathrm{BD}$ are exposed to numerous adverse psychological and health-related outcomes (3). Acute alcohol intoxication includes accidents caused by driving while intoxicated, unwanted sexual behavior, and fights or other disruptive behaviors with possible legal implications. The repeated pattern of alcohol intoxication is related to cognitive impairments $(4,5)$, worse 
health-related quality of life (6), and an increased risk of suffering psychiatric symptomatology/disorders $(7,8)$.

The study of the characteristics or personality traits associated with the engagement of BD patterns, such as possible factors of risk or vulnerability, as well as the influence that consumption has on them, is of great theoretical and applied relevance. In this sense, it is now being suggested that personality is an endophenotype that is sensitive for identifying different subtypes of alcohol use disorders (9), also considering that the modification of behaviors linked to extreme personality traits may be beneficial for prevention and treatment of BD. Focusing on studies in adolescents and young people is not only motivated by the time of appearance and boom of the practice of BD but also because in this period of development and maturation of the organism the biological and behavioral impact of alcohol intoxications is more serious $(4,5)$.

This article reviews existing data on personality characteristics associated with the practice of $\mathrm{BD}$ (considering the several definitions) and its evolution, as well as the possible relationships with other variables that increase the risk or are protective for the maintenance and problematic evolution of the consumption. We also mention limitations and future directions that may allow for progress in this area of research.

\section{METHOD}

The search, selection, and critical assessment of relevant studies were performed according to the PRISMA guidelines (10). The data search was conducted through the computerized databases PubMed and Scopus with "Binge drinking" (or "Heavy drinking" or "Heavy episodic drinking") and "Personality" as keywords, from January 2006 to February 2017 (Figure 1). The search and selection were performed independently and blindly by two authors, and discrepancies resolved by consensus.

\section{RESULTS}

Table 1 presents the studies included in the present review, considering the sample characteristics, BD criteria, assessment of personality, and main results.

\section{Impulsivity and Sensation Seeking}

The two most studied personality traits for BD are Impulsivity and Sensation seeking. Impulsivity is a multidimensional construct associated with poor planning skills, difficulty maintaining attention, and risk-taking behavior. Sensation seeking is defined as the general need for adventure and excitement, the preference for unforeseeable situations and friends, and the willingness to take risks simply for the experience of living them. Many studies have observed higher scores in binge drinkers in both Impulsivity $(11,12,26,27,29)$ and Sensation seeking $(12,16,22,25,26,30$, $31,34)$, when compared with non-binge drinkers. Both traits are considered risk factors for lifetime, whose joint presence has been labeled as "disinhibited personality" (18), although they are especially present in adolescence, characterized by increased impulsive decision making and behavior (40). Similarly, the scores of Impulsivity and Sensation seeking are related to the number of drinks consumed per episode $(14,20,23)$ and the frequency of $\mathrm{BD}(17,18,23)$.

The existing data have been obtained independently of the personality model or the measurement instrument used, either by conceptualizing Impulsivity and Sensation seeking as independent but related features or considering Sensation seeking as a facet of impulsivity. In this second case, the meta-analysis of Stautz and Cooper (40) about the Impulsivity facets as risk factors for problematic alcohol use in adolescence, including BD, were in this order: Sensation seeking, Lack of premeditation, Negative urgency, and Lack of perseverance. These are the dimensions evaluated by the UPPS Impulsive Behavior Scale, frequently used in this field of study. The Negative urgency or tendency to act rashly when experiencing negative emotions is related to $\mathrm{BD}(34,35)$ and is also the only facet related to its severity (16) and to alcohol use disorders as well (34). According to this, BD has been conceptualized as a maladaptive short-term coping strategy devoted to relieving negative affective states (16), which is congruent with the expectations of tension reduction with alcohol that present the binge drinkers, especially in men (14). In the same way, the consideration of facets from Sensation seeking (Thrill and adventure, Experience seeking, Disinhibition, and Boredom susceptibility) indicates that Thrill and adventure and Boredom susceptibility are associated with BD (3). Both facets are externalizing and have psychopathological connections, according to the model of Krueger et al. (41).

A very relevant aspect is that the relationship between $\mathrm{BD}$ and Impulsivity and/or Sensation seeking can be modulated by several factors. It should be noted that personality profile of $\mathrm{BD}$ could be modulated by sex since the highest levels of Impulsivity and/ or Sensation-Seeking come from the men's scores $(11,12,29)$. Moreover, Sensation seeking is the strongest predictor of personality for discriminating binge drinkers from non-drinkers and moderate drinkers in men (22). The expectancies of consumption are mediating in the relationships between the personality traits and BD. Thus, binge drinkers with high Impulsivity show positive expectancies (17), whereas in subjects with high Sensation seeking the greater frequency of episodes of $\mathrm{BD}$ is modulated by the positive consequences from drinking (23). Recent work by Lannoy et al. (24) points to the existence of three types of binge drinkers according to their facets of Impulsivity and drinking motives: Emotional (higher Sensation seeking and Urgency), Recreational (higher Lack of Premeditation and Perseverance), and Hazardous (moderate to high drinking motives). This proposal represents an advance with possible practical implications in the future.

\section{The Big Five Personality Model}

This personality model considers five dimensions: Extraversion, Neuroticism/Emotional stability, Conscientiousness, Openness (to new experiences)/Intellect, and Agreeableness. Personality data using the Big Five model are inconclusive in cross-sectional studies of BD. High Extraversion is the feature most consistently associated with $\operatorname{BD}(22,29,31)$, also being related to a higher frequency of $\mathrm{BD}$ and more negative consequences (37). In relation to Conscientiousness, which negatively correlated with impulsivity (42), although binge drinkers exhibit usually low scores $(5,19,32,37)$, high values (especially in men) have been 


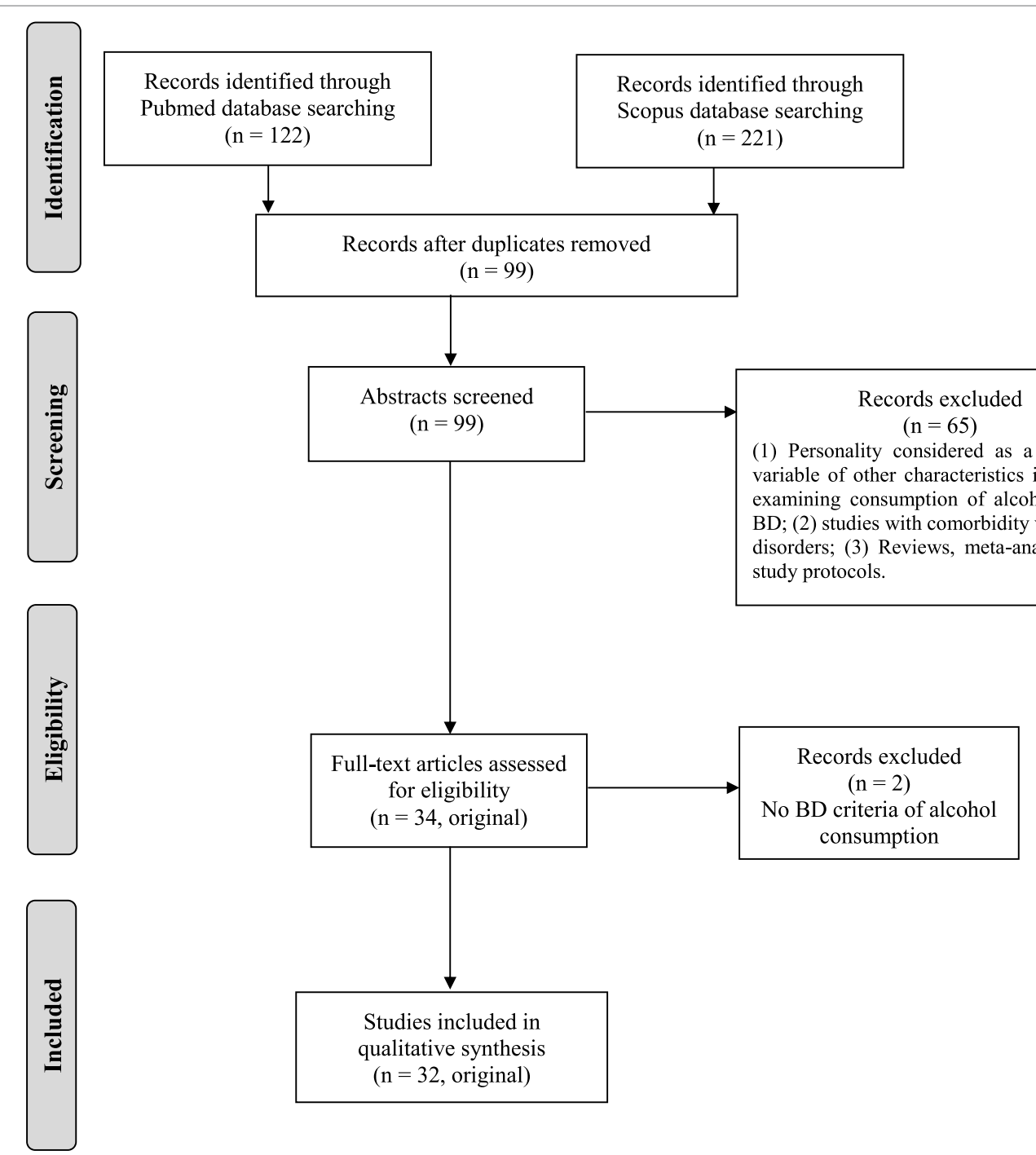

FIGURE 1 | Flowchart for the selection of articles, bibliographic search from January 2006 to February 2017.

also described (29). In this sense, a lower level of self-oriented Perfectionism, which could be considered as a form of hyper Conscientiousness, has also been observed in BD (21). Low Conscientiousness is considered as associated with less prosocial and more health-promoting behaviors (dietary and lifestyles) in general (43). Finally, high Openness has been related to BD in women (28). Some studies have not found relationships between these personality characteristics and $\operatorname{BD}(32,33)$, although they are characterized for including small samples of $\mathrm{BD}$, basically of social drinkers.

The Neuroticism/Emotional stability is the strongest predictor of personality trait that discriminates between binge drinkers and non-drinkers and moderate drinkers in women (22), with low scores in binge drinkers. This could suggest that a higher emotional instability avoids heavy alcohol intake. However, with the Zuckerman personality model (ZKPQ), a higher Neuroticismanxiety has been observed in binge drinkers, although this is a consequence of the results from women (12). High levels of Neuroticism also explain the negative consequences of alcohol consumption in both sexes (29). The review by De Wever and Quaglino (44) suggests the need to study further the involvement of affective factors (anxiety and depression), which may be premorbid and appear or are aggravated by the consumption. Neuroticism is precisely the most important personality dimension related to many forms of psychopathology, including anxiety, depression, and substance use disorders (12).

Other traits of interest studied are the type-D personality and the Boredom proneness. The first is characterized by a high tendency toward experiencing negative emotions and inhibiting the expression of emotions and behaviors in social situations. Boredom proneness is associated with undesirable emotional states such as depression, hopelessness, loneliness, amotivational orientation and is negatively related to life satisfaction and autonomy orientation. Both are considered risk variables for 
TABLE 1 | Results of the empirical studies published on binge drinking (BD) and personality traits (from 2006 to February 2017 ), according to the characteristics of the sample, BD criteria, and the assessment instruments used.

\begin{tabular}{|c|c|c|c|c|}
\hline Reference & Sample characteristics & BD criteria & Personality instruments & Main results \\
\hline \multirow[t]{2}{*}{ Adan (11) } & $\begin{array}{l}160 \text { university students, } \\
80 \text { binge/ } 80 \text { non-binge } \\
\text { drinkers ( } 40 \text { women in } \\
\text { each group) } \\
21.38 \text { years }\end{array}$ & $\begin{array}{l}\geq 4 / 5 \text { drinks for women/men } \\
\text { within } 2 \mathrm{~h} \text { at least once in the } \\
\text { previous } 30 \text { days }\end{array}$ & $\begin{array}{l}\text { Functional Impulsivity and } \\
\text { Dysfunctional Impulsivity (FIDI) }\end{array}$ & $\begin{array}{l}\text { The scores in Dysfunctional Impulsivity were } \\
\text { higher in the BD group compared to the non- } \\
\text { binge group, while no differences were found in } \\
\text { Functional Impulsivity. } \\
\text { Men showed a higher degree of Functional } \\
\text { and Dysfunctional Impulsivity, although in } \\
\text { Dysfunctional Impulsivity significant differences } \\
\text { were observed only in the BD group. }\end{array}$ \\
\hline & & & & $\begin{array}{l}\text { Circadian typology controlled (all intermediate } \\
\text { type). }\end{array}$ \\
\hline \multirow[t]{2}{*}{ Adan et al. (12) } & $\begin{array}{l}140 \text { university students, } \\
70 \text { binge/70 non-binge } \\
\text { drinkers ( } 40 \text { women in } \\
\text { each group) } \\
21.33 \text { years }\end{array}$ & $\begin{array}{l}\geq 4 / 5 \text { drinks for women/men } \\
\text { within } 2 \mathrm{~h} \text { at least once in the } \\
\text { previous } 30 \text { days }\end{array}$ & $\begin{array}{l}\text { Zuckerman and Kuhlman } \\
\text { personality questionnaire (ZKPQ) }\end{array}$ & $\begin{array}{l}\text { Binge drinkers presented higher scores in the } \\
\text { Neuroticism-Anxiety and Impulsivity-Sensation } \\
\text { seeking dimensions than non-binge drinkers. } \\
\text { The Neuroticism-Anxiety results are mainly due } \\
\text { to the women's scores, while the higher scores } \\
\text { in Impulsivity-Sensation seeking are due mainly } \\
\text { to the men's scores. }\end{array}$ \\
\hline & & & & $\begin{array}{l}\text { Circadian typology controlled (all intermediate } \\
\text { type). }\end{array}$ \\
\hline $\begin{array}{l}\text { Ashenhurst } \\
\text { et al. (13) }\end{array}$ & $\begin{array}{l}2,245 \text { students }(1,345 \\
\text { women) } 18.4 \text { years at } \\
\text { inclusion }\end{array}$ & $\begin{array}{l}\geq 4 / 5 \text { drinks for women/men } \\
\text { at a sitting }\end{array}$ & $\begin{array}{l}\text { Zuckerman and Kuhlman } \\
\text { personality questionnaire (ZKPQ): } \\
\text { only Impulsive and Sensation } \\
\text { seeking scale }\end{array}$ & $\begin{array}{l}\text { Longitudinal study: } 6 \text { years follow-up, from } \\
\text { end of high school to } 2 \text { years after college. } \\
\text { Impulsivity and Sensation seeking at inclusion } \\
\text { were higher in frequent and increasing } \\
\text { trajectories compared to moderate, occasional, } \\
\text { rare, or decreasing trajectories. Only increasing } \\
\text { trajectory enhanced the Impulsivity scores, } \\
\text { while the frequent trajectory showed the highest } \\
\text { decrease in Impulsivity. Sensation seeking } \\
\text { decreased in all groups, but in the increasing } \\
\text { trajectory scores were still the highest. }\end{array}$ \\
\hline Balodis et al. (14) & $\begin{array}{l}428 \text { university } \\
\text { students ( } 152 \text { women) } \\
20.00 \text { years. }\end{array}$ & $\begin{array}{l}\geq 4 / 5 \text { drinks for women/men } \\
\text { on drinking occasions }\end{array}$ & $\begin{array}{l}\text { Barrat Impulsiveness Scale (BIS); } \\
\text { Comprehensive Effects of Alcohol } \\
\text { Questionnaire (CEOA) }\end{array}$ & $\begin{array}{l}\text { Binge drinkers did not exhibit higher Impulsivity } \\
\text { levels than non-binge drinkers. } \\
\text { BIS scores correlated with the number of drinks } \\
\text { consumed and the length of the BD episode } \\
\text { (risk for impaired control). } \\
\text { Women reported higher sociability and sexuality } \\
\text { expectations, whereas men reported greater } \\
\text { tension reduction expectations with alcohol. }\end{array}$ \\
\hline $\begin{array}{l}\text { Bhochhibhoya } \\
\text { et al. (8) }\end{array}$ & $\begin{array}{l}334 \text { university } \\
\text { students ( } 166 \text { women) } \\
20.68 \text { years. }\end{array}$ & $\begin{array}{l}\geq 4 / 5 \text { drinks for women/men } \\
\text { on one occasion the past } \\
30 \text { days }\end{array}$ & $\begin{array}{l}\text { Denollett's type-D personality } \\
\text { scale (DS14) }\end{array}$ & $\begin{array}{l}\text { People with higher risk of type-D personality } \\
\text { and mental disturbance (Kessler Psychological } \\
\text { Distress Scale) showed a higher probability for } \\
\text { drinking more alcohol (including a BD pattern). }\end{array}$ \\
\hline Biolcati et al. (15) & $\begin{array}{l}721 \text { adolescents }(61 \% \\
\text { girls) } 15.98 \text { years. }\end{array}$ & $\begin{array}{l}\geq 4 / 5 \text { drinks for women/men } \\
\text { in one night }\end{array}$ & Boredom Proneness Scale (BPS) & $\begin{array}{l}\text { Boredom proneness predicted drinking social } \\
\text { expectancies. Disinhibition and relief from pain } \\
\text { played an important mediating role between } \\
\text { Boredom and alcohol outcome. }\end{array}$ \\
\hline Bo et al. (16) & $\begin{array}{l}162 \text { university students } \\
\text { (82 women) } \\
\text { 18-25 years. }\end{array}$ & $\begin{array}{l}\text { Binge score based on: } \\
\text { number of drinks/h, number } \\
\text { of times intoxicated, and } \\
\text { percentage of time drunk } \\
\text { when going out drinking }\end{array}$ & UPPS-P Impulsive Behavior Scale & $\begin{array}{l}\text { BD was associated with Sensation seeking, but } \\
\text { when controlling for sex, age, and global alcohol } \\
\text { consumption, only the impulsivity component of } \\
\text { Negative urgency predicted severity of BD. }\end{array}$ \\
\hline $\begin{array}{l}\text { Carlson and } \\
\text { Johnson (17) }\end{array}$ & $\begin{array}{l}302 \text { university } \\
\text { students (198 women) } \\
20.74 \text { years. }\end{array}$ & $\begin{array}{l}\geq 4 / 5 \text { drinks for women/men } \\
\text { within } 2 \text { h during the past } \\
\text { year }\end{array}$ & Barrat impulsiveness scale (BIS) & $\begin{array}{l}\text { Impulsivity scores were related to BD frequency. } \\
\text { Impulsivity was not significantly associated } \\
\text { with drinking for participants with low levels } \\
\text { of positive expectancies but was increasingly } \\
\text { related to alcohol use with higher levels of } \\
\text { positive expectancies. }\end{array}$ \\
\hline
\end{tabular}


TABLE 1 | Continued

\begin{tabular}{llll}
\hline Reference & Sample characteristics & BD criteria & Personality instruments \\
\hline Carlson et al. (3) & 293 university & $\geq 4 / 5$ drinks for & Barrat Impulsiveness Scale (BIS); \\
& students (199 women) & women/men within & Sensation Seeking Scale (SSS-V); \\
20.73 years. & 2 h during the past year & Aggression Questionnaire (AQ)
\end{tabular}

\section{Main results}

Controlling for demographic variables (sex, age, residing away from parents, residing off campus, and parental socioeconomic level), only Motor impulsiveness, Thrill and adventure seeking, and Boredom susceptibility were associated with BD frequency.

With the exception of verbal aggression, aggressive personality traits were no related to BD.

\begin{tabular}{llll}
\hline Castellanos-Ryan & 76 adolescents & $\geq 4 / 5$ drinks for & Substance Use Risk Profile Scale \\
et al. (18) & (55 girls) 14.00 years & women/men on 1 or more & (SURP); Impulsivity and Sensation \\
& at inclusion. & occasions in the past & seeking dimensions \\
& & 6 months
\end{tabular}

Longitudinal study: 2-year follow-up

(14-16 years)

Sensation seeking was associated with the unique variance in $\mathrm{BD}$ frequency and part of this overlap was mediated by rewardrelated disinhibition (go/no-go task). Impulsivity was associated with a 2-year average of conduct disorders symptoms, and deficits in response inhibition (visual tracking Stop task) partially mediated on it.

\begin{tabular}{|c|c|c|c|c|}
\hline Clark et al. (19) & $\begin{array}{l}142 \text { binge-drinking } \\
\text { university students } \\
\text { ( } 98 \text { women) } \\
21.2 \text { years. }\end{array}$ & $\begin{array}{l}\geq 4 / 5 \text { drinks for women/ } \\
\text { men consumed in a row }\end{array}$ & $\begin{array}{l}\text { Neuroticism-Extraversion- } \\
\text { Openness (NEO) Five Factor } \\
\text { Inventory; Positive Alcohol } \\
\text { Metacognitions Scale; Negative } \\
\text { Alcohol Metacognitions Scale }\end{array}$ & $\begin{array}{l}\text { Conscientiousness and positive alcohol } \\
\text { metacognitions about cognitive self- } \\
\text { regulation were the only two predictors of } \\
\text { weekly levels of alcohol use when controlling } \\
\text { for sex. In males, low Conscientiousness and } \\
\text { positive alcohol metacognitions were risk } \\
\text { factors for increased levels of alcohol } \\
\text { use in BD. }\end{array}$ \\
\hline Doumas et al. (20) & $\begin{array}{l}346 \text { high school } \\
\text { students ( } 177 \text { women) } \\
17.2 \text { years. }\end{array}$ & $\begin{array}{l}\geq 3 / 5 \text { drinks for women/ } \\
\text { men in a row in a } \\
2 \text {-h period during the last } \\
2 \text { weeks }\end{array}$ & $\begin{array}{l}\text { Zuckerman and Kuhlman } \\
\text { personality questionnaire (ZKPQ): } \\
\text { Only Impulsive Sensation } \\
\text { seeking scale }\end{array}$ & $\begin{array}{l}\text { Higher levels of Impulsive Sensation seeking } \\
\text { were associated with higher levels of BD. } \\
\text { Protective behaviors in manner of drinking } \\
\text { modulated the results, whereas use of more } \\
\text { drinking strategies in participants with high } \\
\text { Impulsive Sensations seeking diminished the } \\
\text { frequency of BD. }\end{array}$ \\
\hline Flett et al. (21) & $\begin{array}{l}207 \text { university students } \\
\text { (131 women); } 70 \text { binge } \\
\text { drinkers ( } 37 \text { women) } \\
18.89 \text { years. }\end{array}$ & $\begin{array}{l}\geq 5 \text { drinks in a single } \\
\text { occasion in the past } \\
2 \text { weeks }\end{array}$ & $\begin{array}{l}\text { Multidimensional Perfectionism } \\
\text { Scale; Frost Multidimensional } \\
\text { Perfectionism Scale }\end{array}$ & $\begin{array}{l}\text { Binge drinkers, with two or more binge episodes } \\
\text { in the past } 2 \text { weeks, had lower levels of self- } \\
\text { oriented Perfectionism and higher levels of } \\
\text { parental criticism. }\end{array}$ \\
\hline $\begin{array}{l}\text { Lac and } \\
\text { Donaldson (22) }\end{array}$ & $\begin{array}{l}506 \text { university } \\
\text { students ( } 351 \text { women) } \\
19.34 \text { years. }\end{array}$ & $\begin{array}{l}\geq 4 / 5 \text { drinks for women/ } \\
\text { men at least once in } \\
\text { the past } 30 \text { days }\end{array}$ & $\begin{array}{l}\text { Sensation seeking 8-items } \\
\text { version; Big Five Personality } \\
\text { taxonomy }\end{array}$ & $\begin{array}{l}\text { Binge drinkers presented higher scores in } \\
\text { Sensation seeking and Extraversion, and lower } \\
\text { in Neuroticism, than non-drinkers and moderate } \\
\text { drinkers. Sensation seeking was the strongest } \\
\text { personality trait for men and Neuroticism for } \\
\text { women, which discriminated the drinking type } \\
\text { (non-drinkers, moderate drinkers, and binge } \\
\text { drinkers). }\end{array}$ \\
\hline Lang et al. (23) & $\begin{array}{l}206 \text { university students } \\
\text { (110 women) } 19.5 \text { years. }\end{array}$ & $\begin{array}{l}\geq 4 / 5 \text { drinks for women/men } \\
\text { on one occasion in the past } \\
\text { month }\end{array}$ & $\begin{array}{l}\text { Brief Sensation Seeking } \\
\text { Scale-4 (BSSS-4) }\end{array}$ & $\begin{array}{l}\text { Students with high Sensation seeking } \\
\text { reported drinking more and had a higher } \\
\text { frequency of BD than students with low } \\
\text { levels. They also experienced more positive } \\
\text { consequences as a result of their } \\
\text { drinking. } \\
\text { Positive consequences mediated the relation } \\
\text { between Sensation seeking and both drinking } \\
\text { and BD frequency. }\end{array}$ \\
\hline
\end{tabular}


TABLE 1 | Continued

\begin{tabular}{|c|c|c|}
\hline Reference & Sample characteristics & BD criteria \\
\hline Lannoy et al. (24) & $\begin{array}{l}867 \text { binge drinkers } \\
\text { ( } 374 \text { women) and } 924 \\
\text { non-binge drinkers } \\
\text { ( } 388 \text { women) university } \\
\text { students } 21.44 \text { years. }\end{array}$ & $\begin{array}{l}>5 \text { drinks for women/ } \\
\text { men per occasion } \\
\text { (alcohol unit } 10 \mathrm{~g} \text { ) } \\
\text { having between } 0.5 \text { and } 4 \\
\text { occasion per week }\end{array}$ \\
\hline
\end{tabular}

\section{Personality instruments \\ Main results}

UPPS-P Impulsive Behavior

Scale; Drinking Motives

Questionnaire-Revised (DMQ-R)
Binge drinkers had lower scores of Negative urgency and Sensation seeking and higher scores on Lack of premeditation than non-binge drinkers. Binge drinkers were not a unitary group. Drinking profiles:

(1) Emotional: higher values for Negative urgency and Sensation seeking; (2) recreational: higher Lack of premeditation and Lack of perseverance; and (3) Hazardous: moderate to high values of drinking motives (enhancement, social order, coping, conformity).

\begin{tabular}{|c|c|c|c|}
\hline Leeman et al. (25) & $\begin{array}{l}312 \text { university students } \\
\text { (184 women) } \geq 18 \text { years. }\end{array}$ & $\begin{array}{l}\geq 4 / 5 \text { drinks for women/men at } \\
\text { a single sitting }\end{array}$ & $\begin{array}{l}\text { Sensation Seeking Scale } \\
\text { (SSS, form V), only }\end{array}$ \\
\hline
\end{tabular}
Disinhibition subscale

BD predictors were sex (male), intensity of best friend's drinking, and Sensation seeking (disinhibition).

\begin{tabular}{llll}
\hline Leeman et al. (26) & $\begin{array}{l}\text { 3,106 high school } \\
\text { students (1,696 girls) } \\
\text { 15.86 years. }\end{array}$ & $\begin{array}{l}\geq 4 / 5 \text { drinks for women/men in } \\
\text { a row the past } 30 \text { days }\end{array}$ & $\begin{array}{l}\text { Zuckerman and Kuhlman } \\
\text { Personality Questionnaire }\end{array}$ \\
& & (ZKPQ), only Impulsive \\
& Sensation seeking scale
\end{tabular}

\begin{tabular}{llll}
\hline Mackie et al. (27) & $\begin{array}{l}393 \text { adolescents (265 } \\
\text { girls) 13.00 years at }\end{array}$ & $\begin{array}{l}\geq 4 / 5 \text { drinks for women/men } \\
\text { on one occasion in the past } \\
\text { inclusion }\end{array}$ & $\begin{array}{l}\text { Substance Use Risk } \\
\text { Profile Scale (SURP); Brief }\end{array}$ \\
& & $\begin{array}{l}\text { Symptom Inventory (BSI) for } \\
\text { depression and anxiety }\end{array}$
\end{tabular}

Martin et al. (28) 153 women university $\quad \geq 4$ drinks in a time during the Ten-Items Personality Inventory students 19.72 years. past two weeks for assessed Big Five traits

Impulsivity, Sensation seeking, having a paid part-time job and non-participation in extracurricular activities, were positively associated with BD and more alcohol consumption overall. Only Impulsivity had significant associations with related problems (drug and gambling).

Longitudinal study: 18-month follow-up (14-16 years) Individuals that scored higher in Hopelessness and Impulsivity were more likely to report engaging in $\mathrm{BD}$.

Elevated levels of Depression symptoms predicted faster rates of increase in alcohol use. High Anxiety sensitivity and Anxiety symptoms showed a faster rate of increase in alcohol use compared with only high Anxiety sensitivity without Anxiety symptoms. Adolescents with elevated levels of Impulsivity and heavier drinking were less likely to a normative decline in Depression symptoms.

Openness was the only personality trait related to BD. Women with higher levels of Openness who engaged in extreme exercise, fasting, or purging were more at risk for heavy and problematic alcohol use.

\begin{tabular}{llll}
\hline Motos et al. (29) & $\begin{array}{l}213 \text { university students } \\
\text { binge drinkers (121 }\end{array}$ & $\begin{array}{l}\geq 40 / 60 \mathrm{~g} \text { alcohol for women/ } \\
\text { men in } 2 / 3 \mathrm{~h} \text { the past }\end{array}$ & $\begin{array}{l}\text { Reduced Neuroticism- } \\
\text { Eomen) } 18.20 \text { years. }\end{array}$ \\
$\begin{array}{lll}\text { Extraversion-Openness } \\
\text { mons }\end{array}$ & $\begin{array}{l}\text { (NEO) Five Factor Inventory; } \\
\text { Behavioral Inhibition } \\
\text { System (BISys) }\end{array}$
\end{tabular}

\begin{tabular}{llll}
\hline $\begin{array}{l}\text { Mushquash } \\
\text { et al. (30) }\end{array}$ & $\begin{array}{l}317 \text { school students (168 } \\
\text { girls), Canadian aboriginal } \\
16.00 \text { years. }\end{array}$ & $\begin{array}{l}\geq 4 \text { drinks for women/men occasion } \\
\text { on one }\end{array}$ & $\begin{array}{l}\text { Substance Use Risk } \\
\text { Profile Scale (SURP) }\end{array}$ \\
\hline Pilatti et al. (31) & $\begin{array}{l}298 \text { women university } \\
\text { students 18.27 years. }\end{array}$ & $\begin{array}{l}\geq 4 \text { drinks on one } \\
\text { occasion last three } \\
\text { months }\end{array}$ & $\begin{array}{l}\text { BigFive Questionnaire } \\
\text { for Children (BFQ-C); Sensation } \\
\text { Seeking Scale (SSS, form V) }\end{array}$
\end{tabular}

The influence of personality was quite limited. Binge drinkers presented especially high levels of Neuroticism and Extraversion. Impulsivity and Conscientiousness, along with age, explained most of the weekly consumption behavior among men. Only Impulsivity and Neuroticism contributed to explain the consequences of consumption.

Sensation seeking and Hopelessness predicted BD.

All personality traits predicted alcohol-related problems.

Regular drinkers with $\mathrm{BD}$ and moderate drinkers had higher scores in Extroversion and alcohol expectancies for social facilitation than abstainers.

Regular drinkers with BD exhibited, compared to moderated drinkers, higher scores in Extroversion, Experience seeking, Disinhibition, and alcohol expectancies for social facilitation. 
TABLE 1 | Continued

\begin{tabular}{|c|c|c|}
\hline Reference & Sample characteristics & BD criteria \\
\hline Rush et al. (32) & $\begin{array}{l}208 \text { university students } \\
\text { (118 women) } 56 \text { binge } \\
\text { drinkers } 18.54 \text { years. }\end{array}$ & $\begin{array}{l}\geq 4 / 5 \text { drinks for women/men } \\
\text { in a row across at least one } \\
\text { sitting in the past month }\end{array}$ \\
\hline
\end{tabular}

Personality instruments

Neuroticism-ExtraversionOpenness (NEO) Five Factor Inventory

\section{Main results}

Binge drinkers did not differ from non-bingers in the NEO five dimensions when compared with college norms. The comorbidity between binge eating and drinking was related to higher levels of Neuroticism and a tendency to lower Conscientiousness (uncontrolled style of impulse control).

\begin{tabular}{|c|c|c|c|c|}
\hline $\begin{array}{l}\text { Scaife and } \\
\text { Duka (33) }\end{array}$ & $\begin{array}{l}60 \text { young ( } 30 \text { women) } \\
\text { moderate and heavy } \\
\text { social drinkers } \\
20.6 \text { years. }\end{array}$ & $\begin{array}{l}\text { Score calculate by average } \\
\text { drinks per hour, number } \\
\text { of time being drunk in the } \\
\text { previous } 6 \text { months and } \\
\text { percentage of time getting } \\
\text { drunk when drinking }\end{array}$ & $\begin{array}{l}\text { Revised Neuroticism-Extraversion- } \\
\text { Openness (NEO) Five Factor } \\
\text { Inventory; Spielberger State-Trait } \\
\text { Anxiety Inventory (STAI) }\end{array}$ & $\begin{array}{l}\text { Binge drinkers rated lower in Openness } \\
\text { than non-binge drinkers (only approached } \\
\text { significance). } \\
\text { Anxiety ratings did not show any differences } \\
\text { with regard to BD. }\end{array}$ \\
\hline Shin et al. (34) & $\begin{array}{l}190 \text { young ( } 115 \text { women) } \\
\text { from community sample } \\
18-25 \text { years. }\end{array}$ & $\begin{array}{l}\geq 4 / 5 \text { drinks for women/men } \\
\text { in a row at least } 2-3 \text { days per } \\
\text { month in the past year }\end{array}$ & UPPS Impulsive Behavior Scale & $\begin{array}{l}\text { Negative urgency and Sensation seeking were } \\
\text { positively associated with BD and alcohol use } \\
\text { disorders during emerging adulthood. }\end{array}$ \\
\hline Shin et al. (35) & $\begin{array}{l}268 \text { young ( } 139 \text { women) } \\
\text { from community sample } \\
21.9 \text { years. }\end{array}$ & $\begin{array}{l}\geq 4 / 5 \text { drinks for women/ } \\
\text { men in a row at least } \\
2-3 \text { days per month in the } \\
\text { past year }\end{array}$ & UPPS Impulsive Behavior Scale & $\begin{array}{l}\text { Negative urgency played a significant role in BD, } \\
\text { as well as peer use and parental alcoholism. }\end{array}$ \\
\hline Whelan et al. (5) & $\begin{array}{l}692 \text { adolescents ( } 312 \\
\text { girls) } 14.56 \text { years. at the } \\
\text { inclusion }\end{array}$ & $\begin{array}{l}\text { A minimum of three life } \\
\text { time episodes leading to } \\
\text { drunkenness }\end{array}$ & $\begin{array}{l}\text { Novelty-seeking scale of } \\
\text { Temperament and Character } \\
\text { Inventory-Revised (TCl-R); } \\
\text { Neuroticism-Extraversion- } \\
\text { Openness (NEO) Five Factor } \\
\text { Inventory; Substance Use Risk } \\
\text { Profile Scale (SURP) }\end{array}$ & $\begin{array}{l}\text { Longitudinal study: 2-year follow-up } \\
\text { (14-16 years). } \\
\text { Higher Novelty-seeking (Disorderliness and } \\
\text { Extravagance) and lower Conscientiousness } \\
\text { characterized both current and future binge } \\
\text { drinkers. } \\
\text { Agreeableness and Impulsivity classified current } \\
\text { but not future binge drinkers. } \\
\text { Anxiety sensitivity (SURP) predicted only } \\
\text { future BD. }\end{array}$ \\
\hline $\begin{array}{l}\text { Winograd } \\
\text { et al. (36) }\end{array}$ & $\begin{array}{l}988 \text { university students } \\
\text { drinkers ( } 494 \text { women) } \\
18.2 \text { years. }\end{array}$ & $\begin{array}{l}\geq 4 / 5 \text { drinks for women/men in } \\
\text { within a } 2 \mathrm{~h} \text { period }\end{array}$ & $\begin{array}{l}\text { Goldberg's International Personality } \\
\text { Item Pool (IPIP), sober and drunk } \\
\text { assessed }\end{array}$ & $\begin{array}{l}\text { Perceived drunken personality associated } \\
\text { with less Conscientiousness, Openness, } \\
\text { Agreeableness and Neuroticism, and more } \\
\text { Extraversion. Women reported larger decreases } \\
\text { in Conscientiousness, Openness, and } \\
\text { Neuroticism than men. Men reported larger } \\
\text { decreases in Agreeableness (more aggressive } \\
\text { when drunk). } \\
\text { Binge drinkers reported increases in } \\
\text { Extraversion (in contrast to decreases in } \\
\text { non-binge drinkers), and greater decreases } \\
\text { in Neuroticism (more anxiolytic effects) and } \\
\text { Agreeableness. }\end{array}$ \\
\hline $\begin{array}{l}\text { Winograd } \\
\text { et al. (37) }\end{array}$ & $\begin{array}{l}374 \text { university students } \\
\text { (187 drinking buddies; } \\
202 \text { women) } 18.4 \text { years. }\end{array}$ & $\begin{array}{l}\geq 5 \text { drinks at a single sitting } 1 \\
\text { or more times per month }\end{array}$ & $\begin{array}{l}\text { Goldberg's International Personality } \\
\text { Item Pool (IPIP), sober and drunk } \\
\text { assessed }\end{array}$ & $\begin{array}{l}\text { Extraversion was positively associated with } \\
\text { more frequency of BD and more negative } \\
\text { consequences, whereas Conscientiousness } \\
\text { was associated with less BD and fewer } \\
\text { consequences (sober and drunk). } \\
\text { Under intoxication, drinkers reported lower } \\
\text { levels of Agreeableness (impaired control } \\
\text { of aggressiveness and low empathy), } \\
\text { Conscientiousness (lower self-control) and } \\
\text { Openness/Intellect, and higher Extraversion } \\
\text { (more sociability) and Emotional Stability } \\
\text { (more stress-dampening and anxiolytic } \\
\text { effects). }\end{array}$ \\
\hline
\end{tabular}


TABLE 1 | Continued

\begin{tabular}{|c|c|c|c|c|}
\hline Reference & Sample characteristics & BD criteria & Personality instruments & Main results \\
\hline $\begin{array}{l}\text { Winograd } \\
\text { et al. (38) }\end{array}$ & $\begin{array}{l}374 \text { university students } \\
\text { (187 drinking buddies; } \\
202 \text { women) } 18.4 \text { years. }\end{array}$ & $\begin{array}{l}\geq 5 \text { drinks at a single } \\
\text { sitting in the past } 30 \text { days }\end{array}$ & $\begin{array}{l}\text { Goldberg's International } \\
\text { Personality Item Pool (IPIP), } \\
\text { sober and drunk assessed }\end{array}$ & $\begin{array}{l}\text { Personality drunk types: } \\
\text { (1) Intoxication-related decreases in } \\
\text { Conscientiousness and Openness below } \\
\text { average. (2) High in Agreeableness when } \\
\text { sober and decreasing less than average } \\
\text { in Conscientiousness and Openness, and } \\
\text { increasing more than average in Extraversion } \\
\text { when drunk. (3) Intoxication related to larger } \\
\text { decreases in Conscientiousness and Openness } \\
\text { and smaller increases in Extraversion. (4) Low in } \\
\text { Extraversion when sober and increasing more } \\
\text { than average in Extraversion and decreasing } \\
\text { more than average in Conscientiousness when } \\
\text { drunk. }\end{array}$ \\
\hline Zhang et al. (39) & $\begin{array}{l}3,110 \text { young adults } \\
(1,648 \text { women) at } \\
\text { the final recording } \\
30.9 \text { years. }\end{array}$ & $\begin{array}{l}\geq 5 \text { drinks in a row during the } \\
\text { past } 12 \text { months }\end{array}$ & $\begin{array}{l}\text { Mini International Personality } \\
\text { Item Pool (Mini-IPIP) of the } \\
\text { Big Five Personality factors }\end{array}$ & $\begin{array}{l}\text { Longitudinal study: 15-year follow-up, } \\
\text { participants in grades 9-12 (USA) at inclusion. } \\
\text { Risk profiles of personality for frequent BD: } \\
\text { (1) Reserved (high Conscientiousness and low } \\
\text { Extraversion, Openness and Agreeableness). } \\
\text { Those with higher rates of frequent BD may } \\
\text { be at risk for type I alcoholism. (2) Resilient } \\
\text { (high Extroversion, Openness and especially } \\
\text { Agreeableness). Those with a greater tendency } \\
\text { toward social contacts may be more vulnerable } \\
\text { to social drinking circumstances. }\end{array}$ \\
\hline
\end{tabular}

UPPS Impulsivity: Urgency, Lack of premeditation, Lack of perseverance, and Sensation seeking. UPPS-P considers two facets of Urgency: Positive and Negative.

mental health, since type-D personality predicts the amount of alcohol consumed (8) and Boredom proneness influences the social expectancies (15) of BD.

\section{Substance Use Risk Profile Scale (SURP)}

In the area of risk for substance consumption, including alcohol, the SURP scale has been developed, which evaluates four dimensions: Anxiety sensitivity, Sensation seeking, Impulsivity, and Hopelessness (a lower order factor of Neuroticism). To a lesser or greater extent, all of these dimensions appear to be implicated as risk factors in BD. In several studies using the SURP, binge drinkers scored higher in Sensation seeking, Impulsivity and Hopelessness than non-bingers $(5,27,30)$, and all the personality traits were related to alcohol problems (30). This scale, with very adequate psychometric properties, is the one selected to assess personality in the "Preventure" prevention program, which will be discussed later.

\section{Changes and Evolution of the Personality Traits Related to BD}

In longitudinal studies, Impulsivity and Sensation seeking are prognostic factors for the maintenance and intensification of the $\mathrm{BD}$ pattern $(5,13)$ and alcohol/drug-related problems and other disorders $(18,27)$. This is observed independently of the personality instrument of measurement. Ashenhurst et al. (13) proposed a deviant pattern of personality maturation without a reduction in both Impulsivity and Sensation seeking as age increases in young adults who developed an increasing trajectory of $\mathrm{BD}$. Anxiety sensitivity also predicts future $\mathrm{BD}$ (5). Faster rates of increase in alcohol use have been related to high Anxiety sensitivity and coexisting anxiety symptoms (27).

Zhang et al. (39) have proposed several alcohol consumption trajectories, based on a cohort followed for 15 years, which can give meaning to the heterogeneity of existing results with the Big Five model. These authors suggest two risk profiles, the "Resilient" one, more vulnerable to social pressure for drinking, and the "Reserved" one, with higher risk for alcoholism. The first is characterized by high Agreeableness, Extroversion, and Openness, whereas the second is defined by high Conscientiousness and low Extraversion, Openness, and Agreeableness. High Extraversion also appeared related to BD in other longitudinal study (5).

In connection with the consumption expectations, it is interesting to examine the effects on the perceived personality related to intoxication as compared with the sober state. Using the Big Five personality model, it has been observed that binge drinkers report increases in Extraversion, and greater decreases in Neuroticism (anxiolytic effects) and Agreeableness (more aggressive) than non-binge drinkers, a pattern modulated by sex $(36,37)$. Four different drunk types have been noted $(38)$, whose consideration in the future may complement the explanatory model of BD (Table $\mathbf{1}$ ).

\section{Interventions Considering Personality Traits}

There is no doubt that investing time and resources in promoting health at an early age, prior to the onset of consumption, has positive repercussions, including minimizing the pattern of BD. The alcohol selective prevention program "Preventure," a brief 
personality-targeted intervention for youth, is an outstanding example of this strategy (45). This program covers three main components: psychoeducational, motivational interviewing, and cognitive behavioral. The intervention has been particularly effective in preventing the growth of BD in early adolescents of both sexes with high Sensation Seeking and Impulsivity and in girls with higher Anxiety sensitivity. This has been evidenced over 36-month follow-up in Australia (46), at a 24-month postintervention in England (47), and at a 12-month follow-up in the Netherlands (45) to mention only studies with longer follow-up periods.

Although our review is focused on personality, an overall explanatory model of BD must also incorporate attitudes, motives, expectancies, or metacognitions referring to consumption, since these are mediating variables in the relationships between personality and $\mathrm{BD}(17,44)$, in addition to participating in the prediction of alcohol-related problems $(23,30)$. Binge drinkers, regardless of their personality characteristics, exhibit higher alcohol expectancies for social facilitation (31) and positive metacognitions (19) than regular moderate drinkers and abstainers. This is especially important in selective prevention, in which the restructuring of dysfunctional metacognitions (e.g., drinking alcohol to avoid negative judgments from others) may help in the control of drinking, while the establishment of adaptive emotional regulation strategies $(16,24)$ may increase the success of the interventions. As a harm reduction strategy, moreover, educating in protective patterns of drinking is effective in reducing the $\mathrm{BD}$ frequency in individuals with high Impulsivity and Sensation seeking (20).

Prevention should be initiated at an early school age and not limited to specific actions, since the general objective should be to promote the empowerment and integral health of young people. The inclusion of multiple elements to promote protective factors seems to be the best strategy to revert to healthier habits and a better quality of life in the short and long term. From this perspective, and for a greater success of these approaches, it is necessary to consider the personality characteristics that represent a vulnerability factor for the initiation and maintenance of BD.

\section{LIMITATIONS AND FUTURE DIRECTIONS}

There is great heterogeneity in the scales used for personality assessment, based on various theoretical models, which makes it difficult to compare the results of different studies. An effort is required to agree on a measurement instrument that integrates those dimensions or facets that represent the main risk factors in BD. We consider that the use of the SURP is very appropriate. Moreover, when it is complemented with the Big Five dimensions of Conscientiousness (for its relevance in health habits) and Extraversion, it could improve the information collected on personality. Furthermore, only a minority of articles has compared the scores obtained with normative data from their corresponding countries, or in the cases where these do not exist, making some sort of conversion to normative scores $(\mathrm{z}, \mathrm{T}, \ldots)$. That is, finding higher or lower scores of a certain dimension in $\mathrm{BD}$ with respect to another group does not always imply that these are values outside the normal population range.

The epidemiological characteristics of the samples, especially sex, age, and race, are rarely analyzed as factors of interaction with the personality traits associated with BD. Most studies collect this information merely as descriptive of the sample, analyze it independently, or only consider it as a control. It is essential to develop future works that explore the modulating effect of epidemiological variables on representative samples, since the studies that have done so have pointed out that the data are not generalizable to the entire population.

It is also required to consider and control for other variables that are known to influence the appearance and maintenance of $\mathrm{BD}$ when they are not the objective of the study, highlighting the presence of psychiatric symptomatology or mental disorders, stressful life events, and circadian rhythmicity. In relation to the latter, an adequate sleep (48) and a morning typology (49) are protective factors for heavy drinking and for extreme personality traits.

The development of longitudinal studies, a minority to date, is the only way to elucidate the specific weight of the personality traits in the initiation and maintenance of $\mathrm{BD}$ and/or relate problems, as well as the impact of BD practice in personality. At the same time, this would allow us to define the age with the greatest vulnerability and the best time for the implementation of prevention programs.

For an integral and explanatory perspective of $\mathrm{BD}$, studies should integrate also biological and neurocognitive evaluations. $\mathrm{BD}$ is not a unitary phenomenon but consists of a combination of history, personality, and brain domains (5), and this is how it should be examined. Only this approach will help to delineate subgroups of risk for $\mathrm{BD}$ and to interpret different trajectories and consequences of its practice in the short, medium, and long term.

Finally, multicenter and multicountry studies will allow us to explore whether there are sociocultural differences in $\mathrm{BD}$, and whether these require specific adaptations in both preventive and treatment approaches. The "Preventure" program, for example, has only been carried out in Anglo-Saxon countries and its development in a Mediterranean or Latin American country may lead to different effectiveness and may require some methodological adjustment.

\section{AUTHOR CONTRIBUTIONS}

AA and JFN collected the materials and resources needed for this review and wrote this article. DAF provided suggestions and revised each draft of the manuscript.

\section{FUNDING}

This work was supported by a grant from the Spanish Ministry of Economy, Industry and Competitiveness PSI2015-65026 (MINECO/FEDER/UE). The funding sources have no involvement in the planning, conduction or evaluation of this study. 


\section{REFERENCES}

1. Kuntsche R, Kuntsche S, Thrul J, Gmel G. Binge drinking: health impact, prevalence, correlates and interventions. Psychol Health (2017) 32:976-1017. doi:10.1080/08870446.2017.1325889

2. National Institute on Alcohol Abuse and Alcoholism. NIAAA Council Approves Definition of Binge Drinking. NIAAA Newsletter. (2004); N 3. Winter.

3. Carlson SR, Johnson SC, Jacobs PC. Disinhibited characteristics and binge drinking among university student drinkers. Addict Behav (2010) 35:242-51. doi:10.1016/j.addbeh.2009.10.020

4. López-Caneda E, Mota N, Crego A, Velasquez T, Corral M, RodríguezHolguín S, et al. Anomalías neurocognitivas asociadas al consumo intensivo de alcohol (binge drinking) en jóvenes y adolescentes: una revisión. Adicciones (2014) 26:334-59. doi:10.20882/adicciones.39

5. Whelan R, Watts R, Orr CA, Althoff RR, Artigues E, Banaschewski T, et al. Neuropsychological profiles of current and future adolescent alcohol misusers. Nature (2014) 512:185-9. doi:10.1038/nature13402

6. Luquiens A, Falissard B, Aubin HJ. Students worry about the impact of alcohol on quality of life: roles of frequency of binge drinking and drinker self-concept. Drug Alcohol Depend (2016) 167:42-8. doi:10.1016/j.drugalcdep. 2016.07.031

7. Sylvers P, Landfield KE, Lilienfeld SO. Heavy episodic drinking in college students: associations with features of psychopathy and antisocial personality disorders. J Am Coll Health (2011) 59:367-72. doi:10.1080/07448481.2010.5 11363

8. Bhochhibhoya A, Collado M, Branscum P, Sharman M. The role of global mental health and type-D personality in predicting alcohol use among a sample of college students. Alcoholism Treat Q (2015) 33:283-95. doi:10.1080/ 07347324.2015 .1050932

9. Oreland L, Lagravineses G, Toffoletto S, Nisson KW, Harro J, Cloninger CR, et al. Personality as an intermediate phenotype for genetic dissection of alcohol use disorder. JNeural Transm (2017). doi:10.1007/s00702-0161672-9

10. Liberati A, Altman DG, Tetzlaff J, Mulrow C, Gotzsche PC, Ioannidis JPA, et al. The PRISMA statement for reporting systematic reviews and meta-analyses of studies that evaluate health care interventions. PLoS Med (2009) 6(7):e1000100. doi:10.1371/journal.pmed.1000100

11. Adan A. Functional and dysfunctional impulsivity in young binge drinkers. Adicciones (2012) 24:17-22. doi:10.20882/adicciones.113

12. Adan A, Navarro JF, Forero D. Personality profile of binge drinking in university students is modulated by sex. A study using the alternative five factor model. Drug Alcohol Depend (2016) 165:120-5. doi:10.1016/j.drugalcdep.2016. 05.015

13. Ashenhurst JR, Harden KP, Corbin VR, Fromme K. Trajectories of binge drinking and personality change across emerging adulthood. Psychol Addict Behav (2015) 29:978-91. doi:10.1037/adb000016

14. Balodis IM, Potenza MN, Olmstead MC. Binge drinking in undergraduates: relationships with sex, drinking behaviors, impulsivity, and the perceived effects of alcohol. Behav Pharmacol (2009) 20:518-26. doi:10.1097/ FBP.0b013e328330c779

15. Biolcati R, Passini S, Mancini G. "I cannot stand the boredom". Binge drinking expectancies in adolescence. Addict Behav Rep (2016) 3:70-6. doi:10.1016/j. abrep.2016.05.001

16. Bo E, Billieux J, Landro I. Which facets of impulsivity predict binge drinking? Addict Behav Rep (2016) 3:43-7. doi:10.1016/j.abrep.2016.03.001

17. Carlson SR, Johnson SC. Impulsivity is not always associated with students drinking: a moderation study of impulsivity and drinking by positive alcohol expectancies. Addict Behav (2012) 37:556-60. doi:10.1016/j. addbeh.2011.12.007

18. Castellanos-Ryan N, Rubia K, Conrod PJ. Response inhibition and reward response bias mediate the predictive relationships between impulsivity and sensation seeking and common and unique variance in conduct disorder and substance misuse. Alcohol Clin Exp Res (2011) 35:140-55. doi:10.1111/j. 1530-0277.2010.01331.x

19. Clark A, Tran C, Weiss A, Caselli G, Nikcevic AV, Spada MM. Personality and alcohol metacognitions as predictors of weekly levels of alcohol use in binge drinking university students. Addict Behav (2012) 37:537-40. doi:10.1016/j. addbeh.2011.11.035
20. Doumas DM, Miller R, Esp S. Impulsive sensation seeking, binge drinking, and alcohol-related consequences: do protective behavioral strategies help high risk adolescents? Addict Behav (2017) 64:6-12. doi:10.1016/j. addbeh.2016.08.003

21. Flett GL, Goldstein A, Wall A-M, Hewitt PL, Wekerle C, Azzi N. Perfectionism and binge drinking in Canadian students making the transition to university. J Am Coll Health (2008) 57:249-53. doi:10.3200/JACH.57.2.249-256

22. Lac A, Donaldson CD. Alcohol attitudes, motives, norms, and personality traits longitudinally classified nondrinkers, moderate drinkers, and binge drinkers using discriminant functions analysis. Addict Behav (2016) 61:91-8. doi:10.1016/j.addbeh.2016.05.006

23. Lang K, Murphy JG, Monahan CJ, Dennhardt AA, Skidmore JR, McDevittMurphy ME. The role of positive consequences of alcohol in the relation between sensation seeking and drinking. Addict Res Theory (2012) 20:504-10. doi:10.3109/16066369.2012.667854

24. Lannoy S, Billieux J, Poncin M, Maurage P. Binging at the campus: motivations and impulsivity influence binge drinking profiles in university students. Psychiatry Res (2017) 250:146-54. doi:10.1016/j.psychres.2017.01.068

25. Leeman RF, Fenton M, Volpicelli JR. Impaired control and undergraduate problem drinking. Alcohol Alcohol (2007) 42:42-8. doi:10.1093/alcalc/ag1095

26. Leeman RF, Hoff RA, Krishnan-Sarin S, Patock-Peckham JA, Potenza MN. Impulsivity, sensation-seeking, and part-time job status in relation to substance use and gambling in adolescents. J Adolesc Health (2014) 54:460-6. doi:10.1016/j.jadohealth.2013.09.014

27. Mackie CJ, Castellanos-Ryan N, Conrod PJ. Personality moderates the longitudinal relationship between psychological symptoms and alcohol use in adolescents. Alcohol Clin Exp Res (2011) 35:703-16. doi:10.1111/j.1530-0277.2010.01388.x

28. Martin JL, Groth G, Longo L, Rocha TL, Martens MP. Disordered eating and alcohol use among college women: associations with race and big five traits. Eat Behav (2015) 17:149-52. doi:10.1016/j.eatbeh.2015.02.002

29. Motos P, Cortés MT, Giménez JA, Cadaveira F. Predictors of weekly alcohol drinking and alcohol-related problems in binge-drinking undergraduates. Adicciones (2015) 27:119-31. doi:10.20882/adicciones.700

30. Mushquash CJ, Stewart SH, Mushquash AR, Comeau MN, McGrath PJ. Personality traits and drinking motives predict alcohol misuse among Canadian aboriginal youth. Int J Ment Health Addict (2014) 12:270-82. doi:10.1007/s11469-013-9451-4

31. Pilatti A, Cupani M, Pautassi RM. Personality and alcohol expectancies discriminate alcohol consumption patterns in female college students. Alcohol Alcohol (2015) 50:385-92. doi:10.1093/alcalc/agv025

32. Rush CC, Becker SJ, Curry JF. Personality factors and styles among college students who binge eat and drink. Psychol Addict Behav (2009) 23:140-5. doi:10.1037/a.0013167

33. Scaife JC, Duka T. Behavioural measures of frontal lobe function in a population of young social drinkers with binge drinking pattern. Pharmacol Biochem Behav (2009) 93:354-62. doi:10.1016/j.pbb.2009.05.015

34. Shin SH, Hong HG, Jeon S-M. Personality and alcohol use: the role of impulsivity. Addict Behav (2012) 37:102-7. doi:10.1016/j.addbeh.2011. 09.006

35. Shin SH, Lee S, Jeon S-M, Wills TA. Childhood emotional abuse: negative emotion-driven impulsivity, and alcohol use in young adulthood. Child Abuse Negl (2015) 50:94-103. doi:10.1016/j.chaibu.2015.02.010

36. Winograd RP, Littlefiel AK, Martinez J, Sher KJ. The drunken self: the five factor model as an organizational framework for characterizing perceptions of one's own drunkenness. Alcohol Clin Exp Res (2012) 36:1787-93. doi:10.1111/j.1530-0277.2012.01796.x

37. Winograd RP, Stenley D, Sher KJ. Drunk personality: reports from drinkers and knowledgeable informants. Exp Clin Psychopharmacol (2014) 22:187-97. doi:10.1037/a0036607

38. Winograd RP, Stenley D, Sher KJ. Searching for Mr. Hyde: approach to characterizing “types of drunk". Addict Res Theory (2016) 24:1-8. doi:10.3109/16 066359.2015.1029920

39. Zhang J, Bray BC, Zhang M, Lanza ST. Personality profiles and frequent heavy drinking in young adulthood. Pers Individ Dif (2015) 80:18-21. doi:10.1016/j. paid.2015.01.054

40. Stautz K, Cooper A. Impulsivity-related personality traits and adolescent alcohol use: a meta-analytic review. Clin Psychol Rev (2013) 33:574-92. doi:10.1016/j.cpr.2013.03.003 
41. Krueger RF, Markon KE, Patrick CJ, Benning SD, Krammer MD. Linking antisocial behavior, substance use, and personality: an integrative quantitative model of the adult externalizing spectrum. J Abnorm Psychol (2007) 116:645-66. doi:10.1037/0021-843X.116.4.645

42. Whiteside SP, Lyman DR. The five factor model and impulsivity: using a structural model of personality to understand impulsivity. Pers Individ Dif (2001) 30:669-89. doi:10.1016/S0191-8869(00)00064-7

43. Lunn TE, Nowson CA, Worsley A, Torres SJ. Does personality affect dietary intake? Nutrition (2014) 30:403-9. doi:10.1016/j.nut.2013.08.012

44. De Wever E, Quaglino V. Risk factors and psychological vulnerabilities to binge-drinking in youth. Encéphale (2017). doi:10.1016/j.encep.2016.11.004

45. Lammers J, Goossens F, Conrod P, Engels R, Wiers RW, Kleinjan M. Effectiveness of a selective alcohol prevention program targeting personality risk factors: results of interaction analyses. Addict Behav (2017) 71:82-8. doi:10.1016/j.addbeh.2017.02.030

46. Newton NC, Conrod PJ, Slade T, Carragher N, Champion KE, Barret EL, et al. The long-term effectiveness of a selective, personality-targeted prevention program in reducing alcohol use and related-harms: a cluster randomized controlled trial. J Child Psychol Psychiatry (2016) 57:1056-65. doi:10.1111/ jcpp. 12558
47. Conrod PJ, O'Leary-Barrett M, Newton NC, Topper L, Castellanos N, Mackie C, et al. Effectiveness of a selective, personality-targeted prevention program for adolescent alcohol use and misuse. JAMA Psychiatry (2013) 70:334-42. doi:10.1001/jamapsychiatry.2013.651

48. Miller MB, DoBello AM, Lust SA, Meisel MK, Carey KB. Impulsive personality traits and alcohol use: does sleeping help with thinking? Psychol Addict Behav (2017) 31:146-53. doi:10.1037/adb0000241

49. Adan A. A chronobiological approach to addiction. J Subst Use (2013) 18:171-83. doi: 10.3109/14659891.2011.632060

Conflict of Interest Statement: The authors declare that the research was conducted in the absence of any commercial or financial relationships that could be construed as a potential conflict of interest.

Copyright (C) 2017 Adan, Forero and Navarro. This is an open-access article distributed under the terms of the Creative Commons Attribution License (CC BY). The use, distribution or reproduction in other forums is permitted, provided the original author(s) or licensor are credited and that the original publication in this journal is cited, in accordance with accepted academic practice. No use, distribution or reproduction is permitted which does not comply with these terms. 